УДК 336.71

\title{
ФІНАНСОВИЙ СТАН БАНКУ ТА МЕТОДИ ЙОГО ОЦІНКИ В УКРӒ̈НI
}

\author{
Вінниченко О.В., к.е.н, доцент, \\ Гудзь А.В., студентка (ХНУБА)
}

Для забезпечення ефективності функиіонування та розвитку економіки будь-якої країни потрібна стабільна банківська система. Здійснення аналізу фінансового стану банківських установ є пріоритетною задачею органів банківського нагляду, самих банків та професійних учасників ринку. У статті розглянуто підходи до визначення сутності поняття «фінансовий стан банку», а також основні циілі та завдання аналізу фінансового стану банку. Проведено порівняльний аналіз коефіцієнтів, які використовують для аналізу фінансового стану банку, а також розглянуто нормативи, встановлені Національним банком Украӥни. Описана найбільш поширена рейтингова модель оцінки фінансового стану банку - американська система CAMELS. Розглянуто та проаналізовано основні методичні підходи аналізу фінансового стану банку.

Ключові слова: банк, фінансовий стан банку, метод аналізу, коефіцієнт, економічні нормативи, ліквідність, прибутковість, фінансова стійкість, ділова активність банку, рейтинг банку.

\section{ФИНАНСОВОЕ СОСТОЯНИЕ БАНКА И МЕТОДИ ЕГО ОЦЕНКИ В УКРАИНЕ}

\author{
Винниченко А.В., к.э.н., доцент, \\ Гудзь А.В., студентка (ХНУСА)
}

Для обеспечения эффективности функционирования и развития экономики любой страны нужна стабильная банковская система. Осуществление анализа финансового состояния банковских учреждений является приоритетной задачей органов банковского надзора, самих банков и профессиональных участников рынка. В статье рассмотреньл подходы к определению сущности понятия «финансовое состояние банка», а также основные цели и задачи анализа финансового состояния банка. Проведен сравнительный анализ коэффициентов, которые используют для анализа финансового состояния банка, а также рассмотрены нормативы, установленные Национальным банком Украины. Описана наиболее распространенная рейтинговая модель оценки финансового состояния банка - американская система CAMELS. Рассмотрены и проанализированы основные методические подходы анализа финансового состояния банка.

Ключевые слова: банк, финансовое состояние банка, метод анализа, коэффициент, экономические нормативы, ликвидость, прибыльность, финансовая устойчивость, деловая активность банка, рейтинг банка.

(C) Вінниченко О.В., Гудзь А.В. 


\title{
FINANCIAL POSITION OF THE BANK AND METHODS OF ITS ASSESSMENT IN UKRAINE
}

\author{
Vinnychenko O.V., Candidate of Economics Sciences, associate professor, \\ Gudz A.V., student \\ (Kharkov National University of Civil Engineering and Architecture)
}

To ensure the effective functioning and development of the economy of any country, a stable banking system is necessary. The stability of the banking system affects the state of the economy and contributes to its growth, so the analysis of the financial condition of banking institutions is a priority function of state bodies that regulate the banking sector. Reliable and timely analysis of the Bank's financial condition is the key to making effective financial decisions on the part of owners, investors, partners, employees of the tax service and other participants in economic relations aimed at reducing costs, increasing profits and market value of the company. Regular analysis of the Bank's activities allows it to effectively manage active and passive operations in order to maximize profits and ensure a stable financial condition.

The article considers approaches to the definition of the concept «financial condition of a Bank» that currently exist in the literature, and it is established that there are many opinions on the definition of the concept «financial condition of a Bank». But, despite the fact that the opinions of a number of authors coincide, this issue requires further study. The article discusses the main goals and objectives of the analysis of the Bank's financial condition. The main methods of analysis of the Bank's financial condition are defined. These include: coefficient analysis, rating analysis, mathematical and statistical models. A comparative analysis of the coefficients that are used to analyze the financial condition of the Bank, as well as the standards established by the National Bank of Ukraine. The most common rating model for assessing the Bank's financial condition - the American CAMELS system-is described.

Key words: Bank, financial condition of the Bank, method of analysis, coefficient, economic standards, liquidity, profitability, financial stability, business activity of the Bank, rating.

Постановка проблеми. Однією 3 умов ефективного функціонування та розвитку економіки країни $є$ стабільна банківська система. Банківська система - це один 3 головних елементів економічної системи будь-якої держави. Її стабільність відображається на стані економіки та сприяє iii зростанню. Своєчасний аналіз фінансового стану допомагає запобігти більшості проблем, пов'язаних 3 діяльністю банківських установ, а також сприяє зміцненню та стабільності не тільки окремого банку, але й банківської системи в цілому. Здійснення аналізу фінансового стану банківських установ $є$ пріоритетною задачею органів банківського нагляду, банків та професійних учасників ринку.

$$
\text { Аналіз останніх джсрел } \boldsymbol{i}
$$
публікацій. Вагомий внесок у вирішення окремих теоретичних та практичних аспектів, пов'язаних з оцінкою фінансового стану банку зробили такі вітчизняні вчені: О. В. Дзюблюк [8], Р. В. Михайлюк [8], А. М. Герасимович [2], Г. В. Щербакова [22], В. В. Іванов [10], . І. Грушко [7], О. Примостка [17], Є. Ширинська [21], А. Бергер [1], Л. Клаппер [1] та інші. Аналіз літературних джерел щодо фінансового стану банківських установ дозволив 3'ясувати, що низка питань пов'язаних 3 організаційно-економічною оцінкою фінансового стану банку визначена недостатньо.

Виділення невирішених частин загальної проблеми. Ще одним фактором, який обумовлює важливість даної теми дослідження є відсутність єдиної методики оцінки фінансового стану банківської 
установи. Виходячи з цього, можна сказати, що методи оцінки фінансового стану банку потребують подальшого аналізу та розгляду.

Метою cmammi $\boldsymbol{\epsilon}$ аналіз, порівняння та узагальнення теоретичних підходів до оцінки фінансового стану банку.

Виклад основного матеріалу дослідження. У сучасних умовах господарювання, фінансовий стан $\epsilon$ ключовою характеристикою підприємницької діяльності, у тому числі у банківській сфері. Достовірний й своєчасний аналіз фінансового стану банку $\epsilon$ запорукою прийняття ефективних фінансових рішень 3 боку власників, інвесторів, партнерів, працівників податкової служби та інших учасників економічних відносин, спрямованих на зниження витрат, зростання прибутку та ринкової вартості бізнесу в цілому. Регулярне проведення банком аналізу своєї діяльності дає змогу ефективно управляти активними та пасивними операціями для максимізації прибутку і забезпечення стабільного фінансового стану.

Поняття «фінансовий стан банку» більшість вчених трактує через сукупність певних коефіцієнтів (табл. 1).

Таблиия 1

Підходи до визначення поняття «фінансовий стан банку»

\begin{tabular}{|c|c|}
\hline Автори & Трактування поняття \\
\hline 1 & 2 \\
\hline Герасимович А. М. [2] & $\begin{array}{l}\text { Фінансовий стан банку - це оцінка показників фінансової } \\
\text { стійкості, ділової активності, ліквідності, ефективності } \\
\text { управління. }\end{array}$ \\
\hline Іванов В. В. [10] & $\begin{array}{l}\text { Фінансовий стан банку - це система показників достатності } \\
\text { капіталу, якості активів, ліквідності балансу, ефективності } \\
\text { діяльності, рівня управління (менеджменту) банку. }\end{array}$ \\
\hline Загородній А. Г. [9] & $\begin{array}{l}\text { Фінансовий стан банку - це стан економічного суб’єкта, що } \\
\text { характеризується наявністю в нього фінансових ресурсів, } \\
\text { необхідними для господарської діяльності, підтримання } \\
\text { нормального режиму праці та існування, здійснення грошових } \\
\text { розрахунків з іншими економічними суб'єктами. }\end{array}$ \\
\hline Дзюблюк О. В. [8] & $\begin{array}{l}\text { Фінансовий стан банку визначається наявністю у нього } \\
\text { фінансових ресурсів, забезпеченістю грошовими ресурсами, } \\
\text { необхідними для діяльності, підтримки нормального режиму } \\
\text { роботи, здійснення грошових розрахунків } 3 \text { іншими } \\
\text { економічними суб'єктами. }\end{array}$ \\
\hline \multirow[t]{2}{*}{ Борисов А. Б. [5] } & $\begin{array}{l}\text { Фінансовий стан банку - це рівень забезпечення економічного } \\
\text { суб’єкта грошовими коштами для здійснення господарської } \\
\text { діяльності, підтримання нормального режиму роботи та }\end{array}$ \\
\hline & своєчасного проведення розрахунків. \\
\hline Щербакова Г.В.[22] & $\begin{array}{l}\text { Фінансовий стан банку визначається загальним рівнем } \\
\text { ефективності управління його активами і пасивами, при цьому } \\
\text { якість управління ними відображається в основних } \\
\text { коефіцієнтах, що характеризують фінансовий стан банку, } \\
\text { зокрема у показниках достатності капіталу, якості активів, } \\
\text { рентабельності, ліквідності, рівня ризиків. }\end{array}$ \\
\hline
\end{tabular}

Отже, розглянувши наведені фінансовий стан банку - це економічна визначення вітчизняних вчених та категорія, яка характеризує фінансовоекономістів, можемо стверджувати, що економічну діяльність банку за допомогою 
певної системи аналітичних показників у чітко визначений момент часу.

Основним об'єктом аналізу фінансового стану банку $\epsilon$ комерційна діяльність. Водночас суб'єктами можуть бути як банки, так i їхні контрагенти, зокрема інші кредитні установи, аудиторські фірми, реальні і потенційні клієнти та кореспонденти, інші фізичні та юридичні особи [11]. Завдання аналізу фінансового стану банку наведені на рис. 1

Завдання аналізу фінансового стану банку

Визначення джерел, якості і стійкості банківських доходів
Узагальнення результатів аналізу i підготовка рекомендацій для прийнення управлінських рішень, спрямованих на покращення діяльності банку

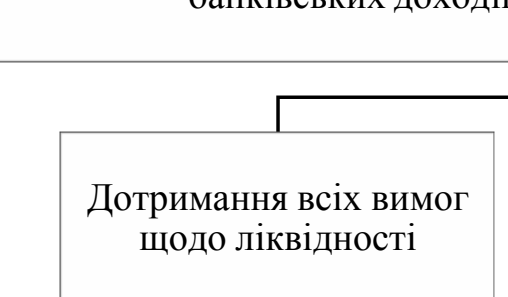

\section{Рис. 1. Завдання аналізу фінансового стану банку Джерело: створено авторами на основі [11]}

В Україні для аналізу фінансового стану банку використовують систему певних коефіцієнтів, які характеризують діяльність банку. У світовій практиці здебільшого використовують рейтингову систему оцінки фінансового стану банку.

Найбільш розповсюдженою методикою аналізу фінансового стану банку $\epsilon$ аналіз 3 використанням фінансових коефіцієнтів, який складається 3 чотирьох основних блоків: 1) оцінка достатності капіталу (фінансової стійкості); 2) розрахунок ліквідності; 3) оцінка ділової активності; 4) оцінка прибутковості.

У табл. 2 наведені основні показники, які використовуються при оцінці фінансового стану за допомогою коефіцієнтного аналізу.

Таблиия 2

Коефіцієнти, запропоновані економістами для аналізу фінансового стану банку [4]

\begin{tabular}{|c|c|c|c|c|c|c|c|c|}
\hline Показники & 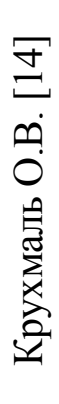 & 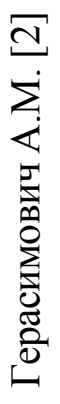 & 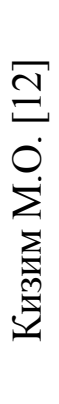 & 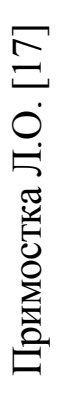 & 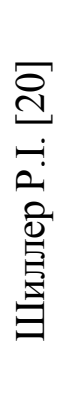 & 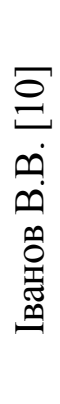 & 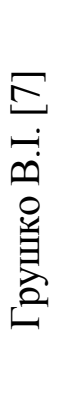 & $\begin{array}{l}\text { Oे } \\
\text { 总 }\end{array}$ \\
\hline 1 & 2 & 3 & 4 & 5 & 6 & 7 & 8 & 9 \\
\hline \multicolumn{9}{|c|}{1 Коефіцієнти ліквідності } \\
\hline Коефіцієнт миттєвої ліквідності & - & + & + & - & + & + & + & 5 \\
\hline Коефіцієнт поточної ліквідності & + & - & + & - & + & - & + & 4 \\
\hline Коефіцієнт загальної ліквідності зобов'язань & - & + & + & - & - & + & - & 3 \\
\hline
\end{tabular}


Продовження табл. 2

\begin{tabular}{|c|c|c|c|c|c|c|c|c|}
\hline 1 & 2 & 3 & 4 & 5 & 6 & 7 & 8 & 9 \\
\hline $\begin{array}{c}\text { Коефіцієнт співвідношення високоліквідних } \\
\text { активів до робочих }\end{array}$ & - & - & - & + & - & - & - & 1 \\
\hline Коефіцієнт ресурсної ліквідності зобов'язань & - & + & - & - & - & + & - & 2 \\
\hline
\end{tabular}

2. Коефіцієнти достатності капіталу (фінансової стійкості)

\begin{tabular}{|c|c|c|c|c|c|c|c|c|}
\hline Коефіцієнт надійності & + & + & + & - & + & + & - & 5 \\
\hline Коефіцієнт фінансового важеля & - & + & - & - & - & + & - & 2 \\
\hline Коефіцієнт достатності капіталу & & + & - & - & + & - & + & 3 \\
\hline Коефіцієнт захищеності власного капіталу & - & - & - & + & - & + & - & 2 \\
\hline Коефіцієнт мультиплікатора капіталу & - & - & + & - & - & + & - & 2 \\
\hline Коефіцієнт незалежності & + & - & - & - & - & + & - & 2 \\
\hline Коефіцієнт активності залучення позикових & - & - & - & - & + & + & - & 2 \\
\hline
\end{tabular}

\begin{tabular}{|c|c|c|c|c|c|c|c|c|}
\hline \multicolumn{7}{|c|}{ 3. Коефіцієнти ділової активності } \\
\hline $\begin{array}{c}\text { Коефіцієнт активності залучення } \\
\text { міжбанківських кредитів }\end{array}$ & - & - & - & - & + & + & - & 2 \\
\hline $\begin{array}{c}\text { Коефіцієнт активності залучення строкових } \\
\text { депозитів }\end{array}$ & - & - & - & - & + & + & - & 2 \\
\hline $\begin{array}{c}\text { Коефіцієнт активності використання } \\
\text { залучених коштів в кредити }\end{array}$ & + & + & - & + & - & - & - & 3 \\
\hline $\begin{array}{c}\text { Коефіцієнт активності використання } \\
\text { строкових депозитів в кредити }\end{array}$ & - & + & - & + & - & - & - & 2 \\
\hline Коефіцієнт кредитної активності & - & - & - & - & - & + & - & 1 \\
\hline $\begin{array}{c}\text { Коефіцієнт загальної інвестиційної } \\
\text { активності }\end{array}$ & - & - & - & - & - & + & - & 1 \\
\hline Коефіцієнт інвестицій в доходних активах & - & - & - & - & - & + & - & 1 \\
\hline Коефіцієнт кредитів в доходних активах & - & - & - & - & - & + & - & 1 \\
\hline Коефіцієнт проблемних кредитів & - & - & - & - & - & + & - & 1 \\
\hline $\begin{array}{c}\text { Коефіцієнт ефективності використання } \\
\text { активів }\end{array}$ & - & - & + & - & - & - & - & 1 \\
\hline 4. Показники ефективності управління (рентабельності) & & \\
\hline Рентабельність активів & + & + & + & + & + & + & + & 7 \\
\hline Рентабельність капіталу & - & - & - & + & + & + & + & 4 \\
\hline Маржа & - & + & - & - & + & + & - & 3 \\
\hline Спред & - & + & - & - & + & + & - & 3 \\
\hline Всього & 5 & 11 & 7 & 6 & 11 & 20 & 5 & \\
\hline
\end{tabular}

Аналіз існуючих підходів дає змогу зробити висновки, що найбільша кількість коефіцієнтів для оцінки фінансового стану банку була запропонована Івановим В. В., Герасимовичем А. М., Шиллер Р. I. та Кизимом М. О. Серед перелічених коефіціснтів найчастіше для аналізу фінансового стану використовують: коефіцієнт достатності капіталу, коефіцієнт надійності, коефіцієнт фінансового важеля та коефіцієнт активності використання залучених коштів в кредити.

Залежно від мети, цілей та завдань аналізу фінансового стану, які ставить перед собою керівництво банку, здійснюється вибір показників для такої оцінки.

Серед закордонних підходів до аналізу фінансового стану банків методом коефіцієнтного аналізу є [6]: 
1) BAKIS (BAKred Information System), яку використовує Центральний банк Німеччини і Федеральне відомство контролю за банками 31997 р. Методика складається 347 коефіцієнтів, 3 яких 19 оцінюють кредитний ризик, 16 ринковий ризик, 2 - ризик ліквідності, 10 прибутковість банку;

2) BMS (Bank Monitoring Screens), яка використовується в США.
Методика охоплює 39 коефіцієнтів і 35 параметрів, що належать до ринку капіталів.

Методика розрахунку економічних нормативів регулювання діяльності банків в Україні розроблена відповідно до вимог Інструкції про порядок регулювання діяльності банків в Україні [16].

У табл. 3 наведено економічні нормативи, що встановлює Національний Банк України, які $є$ обов'язковими для виконання всіма банківськими установами.

Економічні нормативи для банків України, встановлені НБУ

Таблиия 3

\begin{tabular}{|c|c|c|}
\hline № & Назва показника & Нормативне значення \\
\hline \multicolumn{3}{|c|}{ Нормативи капіталу } \\
\hline H1 & Мінімальний розмір регулятивного капіталу & 500 млн. грн. \\
\hline $\mathrm{H} 2$ & Достатність (адекватність) регулятивного капіталу & Не менше $10 \%$ \\
\hline H3 & Достатність основного капіталу & Не менше 7\% \\
\hline \multicolumn{3}{|c|}{ Нормативи ліквідності } \\
\hline $\mathrm{H} 4$ & Миттєва ліквідність & Не менше $20 \%$ \\
\hline H5 & Поточна ліквідність & Не менше $40 \%$ \\
\hline H6 & Короткострокова ліквідність & Не менше $60 \%$ \\
\hline \multicolumn{3}{|c|}{ Нормативи кредитного ризику } \\
\hline $\mathrm{H} 7$ & $\begin{array}{l}\text { Максимальний розмір кредитного ризику одного } \\
\text { контрагента }\end{array}$ & Не більше $25 \%$ \\
\hline $\mathrm{H} 8$ & Великі кредитні ризики & $\begin{array}{c}\text { Не більше 8-кратного } \\
\text { розміру регулятивного } \\
\text { капіталу } \\
\end{array}$ \\
\hline H9 & $\begin{array}{l}\text { Максимальний розмір кредитів, гарантій та } \\
\text { поручительств, наданих одному інсайдеру }\end{array}$ & Не більше 5\% \\
\hline \multicolumn{3}{|c|}{ Нормативи інвестування } \\
\hline H11 & $\begin{array}{l}\text { Інвестування в цінні папери окремо за кожною } \\
\text { установою }\end{array}$ & Не більше $15 \%$ \\
\hline $\mathrm{H} 12$ & Загальна сума інвестування & Не більше $60 \%$ \\
\hline
\end{tabular}

Основною перевагою оцінки фінансового стану банку з використанням аналізу коефіцієнтів $є$ нескладність розрахунків, проте, даний метод $\epsilon$ ефективним при розрахунку великої кількості коефіцієнтів, що робить його громіздким. Зважаючи на те, що коефіцієнтний метод грунтується на бухгалтерській звітності, певна частина якої $\epsilon$ конфіденційною, його можна рекомендувати для розрахунку службами внутрішнього аудиту, наглядовими органами НБУ та іншими органами, які мають доступ до цієї інформації.

Сучасні вітчизняні методики рейтингової оцінки поділяються на номерні, бальні, регресійні, індексні [3]. Особливості основних методів побудови рейтингу та їх принципи представлено у табл. 4 
Таблиия 4

Основні методики побудови рейтингових очінок [3]

\begin{tabular}{|c|c|c|}
\hline Методика & Принцип & Особливості \\
\hline Номерна & $\begin{array}{c}\text { Оцінка здійснюється за кожним } \\
\text { показником окремо }\end{array}$ & $\begin{array}{c}\text { Слабо деталізований метод } 3 \\
\text { невеликою кількістю факторів }\end{array}$ \\
\hline Бальна & $\begin{array}{c}\text { Дозволяє здійснювати оцінку в } \\
\text { балах, що присвоєні кожному } \\
\text { оціночному показнику }\end{array}$ & $\begin{array}{c}\text { Дає можливість визначати } \\
\text { приналежність до певної групи }\end{array}$ \\
\hline Індексна & $\begin{array}{c}\text { Здійснюється розрахунок індексу } \\
\text { для кожного з оціночних } \\
\text { показників }\end{array}$ & $\begin{array}{c}\text { Розрахунки здійснюються } \\
\text { відносно базисних даних або } \\
\text { середніх значень за декілька років }\end{array}$ \\
\hline Регресійна & $\begin{array}{c}\text { Визначається певна сукупність } \\
\text { банків, розраховується значення } \\
\text { факторних показників щодо } \\
\text { кожного банку і середніх за } \\
\text { сукупністю } \\
\end{array}$ & $\begin{array}{c}\text { Використовується кореляційно- } \\
\text { регресійний аналіз для визначення } \\
\text { взаємозв'язку між результатами } \\
\text { діяльності досліджуваних об'єктів } \\
\text { і чинниками, які їх визначають }\end{array}$ \\
\hline
\end{tabular}

Джерело: складено авторами на основі [3]

Номерні методики передбачають обчислення сукупності значень обсягових та інших показників фінансового стану банків і присвоєння всім банкам певного місця в рейтингу за кожним 3 оцінюваних показників. Ці методики є досить простими, але вони фактично не дозволяють оцінити фінансову стійкість банків [3].

Бальна методика дає змогу оцінювати фінансовий стан банку в балах, присвоєних йому за кожним оціночним показником. Зведена бальна оцінка банку дає можливість визначати приналежність останнього до тієї або іншої групи банків [13].

Індексні методики набули поширення внаслідок простоти їхнього застосування. Ці методики $\epsilon$ достатньо точними, проте головна проблема полягає у виборі найважливіших фінансових показників, що ïх потрібно враховувати, і які максимально би відображали усі аспекти діяльності банків. Вибрати їх не завжди вдається правильно [19].

Регресійна методика визначає певну сукупність банків, розраховує значення факторних показників щодо кожного банку i середніх за сукупністю. 3 метою елімінування масштабу показників обчислюють узагальнюванні показники як відношення розрахунку окремих банків до середнього значення за сукупністю, потім усереднюються узагальнюванні показники шляхом розрахунку середніх величин [18].

До розповсюджених рейтингових моделей, які використовуються у вітчизняній банківській практиці, можна віднести американську систему CAMELS, сутність якої полягає у визначенні загального стану банку на основі єдиних критеріїв, що охоплюють усю його діяльність (табл.5).

Система CAMELS допомагає визначати банки, фінансовий стан, операції або менеджмент яких мають недоліки, що здатні призвести до банкрутства.

Параметри системи CAMELS оцінюються за п'ятибальною шкалою, де «1» $\epsilon$ найвищою оцінкою, а «5» найнижчою. На підставі оцінок усіх параметрів за п'ятибальною шкалою складається зведений рейтинг [4].

Під банківським рейтингом слід розуміти узагальнюючу оцінку діяльності банку, на основі якої можна визначити положення певного банку відносно інших банківських установ. Спостереження за рейтинговою позицією конкретного банку та іï аналіз сприяють виробці обгрунтованих рішень стосовно подальших відносин клієнтів із банківською установою. 
Табличя 5

Параметри системи CAMELS [20]

\begin{tabular}{|c|c|c|c|}
\hline \multicolumn{2}{|c|}{ Назва параметра } & \multicolumn{2}{|c|}{ Характеристика параметра } \\
\hline C & Capital adequacy & $\begin{array}{c}\text { достатність } \\
\text { капіталу }\end{array}$ & $\begin{array}{c}\text { Визначає достатність капіталу для покриття } \\
\text { ризикованих відкритих позицій }\end{array}$ \\
\hline A & Asset quality & якість активів & $\begin{array}{c}\text { Визначає ступінь ризикованості активів банку } \\
\text { Мцінює якість банківського менеджменту на } \\
\text { основі оцінки всієї фінансової звітності i } \\
\text { визначення результатів діяльності }\end{array}$ \\
\hline E & Earnings & надходження & $\begin{array}{c}\text { Визначає достатність доходів для майбутньго } \\
\text { росту банку та формування резервів для } \\
\text { покриття очікуваних ризиків }\end{array}$ \\
\hline L & Liquidity & ліквідність & $\begin{array}{c}\text { Визначає ступінь спроможності банку } \\
\text { виконувати свої зобов'язання }\end{array}$ \\
\hline Sensitivity to & $\begin{array}{c}\text { чутливість до } \\
\text { ринкового } \\
\text { ризику }\end{array}$ & $\begin{array}{c}\text { Оцінює вплив ринкового ризику на } \\
\text { прибутковість та капітал банку }\end{array}$ \\
\hline
\end{tabular}

Математично-статистичні методи $€$ найновішим інструментом оцінювання фінансової стійкості банків i, хоча в науці вини $\epsilon$ загальновизнаними, однак були впроваджені у практику зарубіжних країн протягом останніх 10-15 років. Їх обмежене використання можна пояснити математичною складністю та потребою володіння знаннями в галузі теорії ймовірності та математичної статистики. Варто зазначити, що ці методи дають змогу при використанні неконфіденційної інформації здійснювати глибокий та грунтовний аналіз та отримати більш об'єктивну оцінку фінансової стійкості банку, ніж це можливо рейтинговими методами, які вимагають врахування експертних уподобань [6].

Треба зазначити, що математичностатистичні методи не призначені для аналізу окремих банків, адже потребують врахування характеристик всієї сукупності. Тому доцільно використовувати дані методи у аналізі певної групи банків або банківської системи в цілому.
Переваги та недоліки основних методів оцінки фінансового стану банку наведено у табл.6.

Як видно 3 табл. 6, рейтингові та математично-статистичні методи мають найбільшу кількість переваг. Метод коефіцієнтів має такі переваги, як простота обчислень, точність та комплексність аналізу та характеризується такими недоліками, як громіздкість та відсутність програмного забезпечення. Математично-статистичні методи за недолік мають математичну складність. Порівняння основних методів аналізу фінансового стану банку дало змогу виділити переваги та недоліки кожного підходу.

Отже, проведений аналіз методів оцінки фінансового стану банку дозволяє зробити наступний висновок: використання лише одного методу аналізу для представлення поточного i майбутнього фінансового стану банку $\epsilon$ недостатнім. Виходячи 3 цього, постає необхідність в розробці комплексної методики аналізу фінансового стану банку, яка включала б всі складові аспекти. 
Переваги та недоліки методів оцінки фінансового стану банку [6]

\begin{tabular}{|c|c|c|c|}
\hline Ознака & 它 & 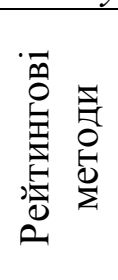 & 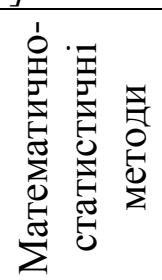 \\
\hline \multicolumn{4}{|l|}{ Переваги: } \\
\hline Простота обчислень & + & + & \\
\hline Точність аналізу & + & & + \\
\hline Комплексність аналізу & + & + & + \\
\hline Можливість узагальненої оцінки & & + & + \\
\hline Експертні технології & & + & + \\
\hline $\begin{array}{l}\text { Можливість порівняльного аналізу для великої кількості } \\
\text { банків }\end{array}$ & & + & + \\
\hline \multicolumn{4}{|l|}{ Недоліки: } \\
\hline Громіздкість & - & & \\
\hline Математична складність & & & - \\
\hline Відсутність програмного забезпечення & - & - & \\
\hline
\end{tabular}

Висновки. Проаналізувавши підходи науковців до оцінки фінансового стану банку, можна зробити висновки, що дані методи є абсолютно несхожими відносно характеру та кількості основних показників. Більшість методик основаних на коефіцієнтному аналізі поєднує три групи показників, що дають можливість оцінити фінансовий стан банку виходячи із: оцінки фінансової стійкості; оцінки ділової активності; оцінки ліквідності.

Оцінка фінансового стану необхідна для вирішення проблем банку, пов'язаних 3 його надійністю, стабільністю на конкурентному ринку, та подальшим розвитком. Отже, сьогодні існує велика кількість методів та методик аналізу фінансового стану банку. Використання інформаційних технологій у банківській сфері приводить до створення більш вдосконалених та точних систем оцінювання стану банків. У наш час методики включають математичностатистичні методи, експрес-методи на основі коефіцієнтного аналізу та методи, основані на рейтинговій системі. При цьому важливим $\epsilon$ визначення i усвідомлення основних переваг і недоліків використання певних методів оцінки фінансового стану підприємства, умов за яких доцільним $є$ використання того чи іншого методу.

\section{ПЕРЕЛІК ВИКОРИСТАНИХ ДЖЕРЕЛ}

1. Berger, A. ; Klapper, L. ; and Turk-Ariss, R. «Bank Competition and Financial Stability» // Journal of Financial Services Research, 35(2009), 99-118. URL :https://openknowledge.worldbank.org/handl e/10986/6794.

2. Аналіз діяльності: [A. М. Герасимович, I. М. ПарасійВергуненко, В. М. Кочетков та ін.]; за заг. ред. д-ра економ. наук, проф. А. М. Герасимовича. - К. : КНЕУ, 2010. $599 \mathrm{c}$. 3.
Батковський
B.
A. Рейтингова оцінка діяльності банків / В. А. Батковський // Фінанси України. 2004. - № 5. - C. 145-150.

4. Бобиль В. Використання показників рівня якості управління ризиками в процесі оцінювання 
фінансового стану банку [Електронний pecypc]. - Режим доступу http://eadnurt.diit.edu.ua/bitstream/12345678 9/2081/1/Bobyl_11.pdf.

5. Борисов А. Б. Большой экономический словарь. Издание 2-е, переработанное и дополненное / А. Б. Борисов. - М. : Книжный мир, 2005. -860 c.

6. Вольська С. П. Порівняльна характеристика методів оцінювання фінансової стійкості банку / С.П. Вольська // Серія Економічні Науки. - 2015. №10(1). - С. 178-181.

7. Грушко В. I. Системна модель аналізу фінансової стійкості комерційного банку / B.I. Грушко, Л. Ю. Петриченко // Фінанси України. 2001. - № 12. - C. 20-28.

8. Дзюблюк О. В. Фінансова стійкість банків як основа ефективного функціонування кредитної системи : монографія / О. В. Дзюблюк, Р. В. Михайлюк. - Тернопіль : Терно-граф, 2009. - 316 c.

9. Загородній А. Г. Фінансовоекономічний словник / А. Г. Загородній, Г. Л. Вознюк. - Львів : «Львівська політехніка», 2005. - 714 с.

10. Иванов В. В. Анализ надежности банка: практическое пособие / В. В. Иванов. - М. : Русская Деловая Литература, 1996. - 320 с.

11. Карась П. М. Банківська система : навчальний посібник / П. М. Карась, Н. В. Приходько, О. В. Пащенко, Л. О. Гришина. - Херсон : ОЛДІ-ПЛЮС, 2015. - 292 с.

12. Кизим Н. А. Моделирование банкротства коммерческих банков / Н. А. Кизим, И. С. Благун, В. А. Зинченко, Чанг Хонг Вен. - Х. : ИНЖЕК, 2003. - 220 с.

13. Косова Т. Д. Аналіз банківської діяльності : навчальний посібник / Т. Д. Косова. - К. : Центр учбової літератури, 2008. - 486 с.

14. Крухмаль О. В. Оцінка фінансової стійкості банків:інформаційне і методичне забезпечення : автореф. дис. к- та екон. наук / О. В. Крухмаль. - Суми, 2007. $-20 \mathrm{c}$.

15. Лисенко О. В. Інтегральна рейтингова модель оцінки фінансового стану банків / О. В. Лисенко // Ефективна економіка - 2012. - №9 [Електронний pecypc]. - Режим доступу : http://www.economy.nayka.com.ua/?op=1\&z $=228$.

16. Постанова Правління НБУ «Про затвердження Інструкції про порядок регулювання діяльності банків України» [Електронний ресурс]. - Режим доступу

https://zakon.rada.gov.ua/laws/show/z084101.

17. Примостка Л. О. Банківські ризики. Теорія та практика управління : монографія / Л. О. Примостка та ін. - К. : KHEУ, 2008. - 450 c.

18. Рисін М. В. Рейтингова оцінка діяльності банків як інструмент аналізу фінансового стану / М. В. Рисін // Вісник Університету банківської справи Національного банку України. - 2014. - № 2. - С. 159-164. [Електронний ресурс]. Режим доступу: http://nbuv.gov.ua/UJRN/VUbsNbU_2014_2 -34.

19. Фалюта А. Аналіз індексних методик оцінювання фінансового стану банків / А. Фалюта // Економічний аналіз. - 2012. -№ 10(3). - C. 103-106. [Електронний ресурс]. - Режим доступу: http://nbuv.gov.ua/UJRN/ecan_2012_10(3)_ 24.

20. Шиллер P.I. Фінансова стійкість комерційного банку та шляхи іiі зміцнення / P.І. Шиллер. - Київ : Наукова думка, 1998. - 158 с.

21. Ширинська $€$. Рейтинг i лімітна політика банків // Вісник НБУ. 2016. - № 5. - C. 29-31.

22. Щербакова Г. Н. Анализ и оценка банковской деятельности / Г. Н. Щербакова. - М. : Вершина, 2007. $464 \mathrm{c}$. 


\section{REFERENCES}

1. Berger, A. ; Klapper, L. ; and Turk-Ariss, R. «Bank Competition and Financial Stability»// Journal of Financial Services Research, 35(2009), 99-118. URL : https://openknowledge.worldbank.org/handle /10986/6794.

2. Analiz bankivskoi diialnosti [AM Herasymovych, IM ParasiiVerhunenko, VM Kochetkov ta in.]; za zah. red. d-ra ekonom. nauk, prof. AM Herasymovycha (2010) [Analysis of banking activities]. Kyiv: KNEU.

3. Batkovsjkyj VA (2004) Rejtynghova ocinka dijaljnosti bankiv [Rating assessment of banks' activity]. Finansy Ukrajiny, no. 5, pp. 145-150.

4. Bobyl V Vykorystannia pokaznykiv rivnia yakosti upravlinnia ryzykamy $\mathrm{v}$ protsesi otsiniuvannia finansovoho stanu banku [Use of indicators of the quality level of risk management in the process of evaluating the financial condition of the bank]. - URL: http://eadnurt.diit.edu.ua/bitstream/12345678 9/2081/1/Bobyl_11.pdf.

5. Borisov AB (2005) Bol'shoy ekonomicheskiy slovar' [Big economic dictionary]. Moscow: Book World.

6. Voljsjka SP (2015)

Porivnjaljna kharakterystyka metodiv ocinjuvannja finansovoji stijkosti banku [Comparative characteristics of methods for assessing the financial stability of the Bank]. Serija Ekonomichni Nauky, no. 10(1), pp. 178-181.

7. Hrushko VI , Petrychenko LYU (2001) Systemna model' analizu finansovoyi stiykosti komertsiynoho banku [System model of financial bank financial stability analysis]. Finance of Ukraine, no. 12, pp. 20-28.

8. Dzyublyuk OV, Mykhaylyuk RV (2009) Finansova stiykist' bankiv yak osnova efektyvnoho funktsionuvannya kredytnoyi systemy [Financial stability of banks as a basis for efficient functioning of the credit system]. Ternopil: Terno-h.
9. Zahorodniy AH, Voznyuk HL (2005) Finansovo-ekonomichnyy slovnyk [The financial and economic dictionary]. Lviv: Lviv Polytechnic.

10. Ivanov VV (1996) Analiz nadezhnosti banka [Bank reliability analysis]. Moscow: Russian business literature.

11. Karas' PM, Prykhod'ko NV, Pashchenko OV, Hryshyna LO (2015) Bankivs'ka systema [Banking system]. Kherson: OLDI-PLUS.

12. Kizim NA, Blagun IS, Zinchenko VA, Chang Khong Ven (2003) Modelirovaniye bankrotstva kommercheskikh bankov [Modeling bankruptcy of commercial banks]. Kharkov: INZHEK.

13. Kosova TD (2008) Analiz bankivsjkoji dijaljnosti [Analysis of banking activities]. Kiev : Centr uchbovoji literatury.

14. Krukhmal' OV (2007) Otsinka finansovoyi stiykosti bankiv:informatsiyne i metodychne zabezpechennya [Assessment of financial soundness of banks: information and methodological support] ( $\mathrm{PhD}$ Thesis), Sumy.

$$
\text { 15. Lysenko OV (2012) }
$$

Intehral'na reytynhova model' otsinky finansovoho stanu bankiv [An integrated rating model for assessing banks' financial condition]. An efficient economy, no. 19, URL:

http://www.economy.nayka.com.ua/?op=1\&z $=228$.

16. Resolution of the NBU Board «Pro zatverdzhennya Instruktsiyi pro poryadok rehulyuvannya diyal'nosti bankiv Ukrayiny» [On approval of the Instruction on the procedure for regulating the activity of Ukrainian banks]. URL: https://zakon.rada.gov.ua/laws/show/z084101 .

17. Prymostka LO (2008) Bankivs'ki ryzyky. Teoriya ta praktyka upravlinnya [Banking risks. Management theory and practice]. Kyiv: KNEU.

18. Rysin MV (2014) Rejtynghova ocinka dijaljnosti bankiv jak instrument analizu finansovogho stanu [Rating 
assessment of banks' activity as a tool for analyzing the financial state]. Visnyk Universytetu bankivsjkoji spravy Nacionaljnogho banku Ukrajiny, no. 2, pp. 159-164.

19. Faljuta A (2012) Analiz indeksnykh metodyk ocinjuvannja finansovogho stanu bankiv [Analysis of index methods for assessing the financial condition of banks]. Ekonomichnyj analiz, no. 10(3), pp. 103-106.

20. Shyller RI (1998) Finansova stiykist' komertsiynoho banku ta shlyakhy yiyi zmitsnennya [Financial stability of a commercial bank and ways to strengthen it]. Kiev: Scientific Opinion.

21. Shyryns'ka YE (2016)

Reytynh i limitna polityka bankiv [Banks rating and marginal policy]. Bulletin of the NBU, no. 5, pp. 29-31.

22. Shcherbakova GN (2007) Analiz i otsenka bankovskoy deyatel'nosti [Analysis and assessment of banking]. Moscow : Top. 